\title{
FACTORS AFFECTING THE TRANSLATION, INTERPRETATION, AND EXTRAPOLATION ABILITIES IN ELEMENTARY SCHOOL STUDENTS' LEARNING ACHIEVEMENT
}

\author{
Sri Wuryanti ${ }^{1 *}$, Deni Hadiana ${ }^{1}$, Rumondang Purwati ${ }^{1}$ \\ ${ }^{1}$ Department of Research and Development, Kementerian Pendidikan dan Kebudayaan \\ Jl. Jend. Sudirman, Gelora, Tanah Abang, Kota Jakarta Pusat, Jakarta 10270, Indonesia \\ *Corresponding Author. E-mail: sriwuryanti03@gmail.com
}

\begin{abstract}
This study was to determine the correlation between translation, interpretation, and extrapolation abilities on the learning achievement of elementary school students in science subjects. The research method was descriptive quantitative. Data collection techniques used tests to understand the concepts of translation, interpretation, and extrapolation with test techniques and students' learning achievement with secondary data. Product moment and regression test were used in data analysis. The research results show that (1) there is a correlation between translation ability and the level of science learning achievement of grade V students; the significance level is satisfactory. (2) There is a correlation between the interpretation ability and the level of science learning achievement of grade V students; the significance level is satisfactory. (3) There is a correlation between extrapolation ability and the level of science learning achievement of grade V students; the significance level is very satisfactory. (4) There is a correlation between the ability of translation, interpretation, and extrapolation on the science learning achievement of grade V students; the level of significance is very satisfactory.
\end{abstract}

Keywords: translation, interpretation, extrapolation, science, elementary school, learning achievement

How to cite: Wuryanti, S., Hadiana, D., \& Purwati, R. (2020). Factors affecting the translation, interpretation, and extrapolation abilities in elementary school students' learning achievement. Jurnal Penelitian dan Evaluasi Pendidikan, 24(2), 198-207. doi:https://doi.org/10.21831/pep.v24i2.35730

\section{INTRODUCTION}

Educational goals are to optimize cognitive, affective, and motoric skills to develop the cognitive domain optimally if it gets right stimulation from educational environment, family support, and the social environment of society. This study is to determine the cognitive abilities of students in science subjects. Meanwhile, one of the cognitive abilities is understanding the concept because a good understanding of concept will optimize students' learning achievement. Understanding concepts in this study are cognitive concepts including translation, interpretation, extrapolation. Hurlock (1990) states that conceptual understanding is determining what a person regulates, so understanding the concept will determine a positive attitude emotionally burdened with emotional attitudes or acceptance, it will encourage positive action and vice versa; if it is negative, it will lead to antagonistic action. Understanding the concept, according to Arends (2001), is someone in classifying an object and a network of ideas to determine principles and rules, all of which are the foundation of how a network of thoughts or ideas can be arranged for human to think. According to Seymour (1966), understanding of the concept is very valuable to help students reduce simple and easy to manage information; understanding new situations by generalizing the concepts they have. Capital to see abstract ideas without having to present all the underlying ideas and improving the way of thinking by using 
memory with full attentions in capturing information is reduced to main ideas and packaged into concepts. According to Crowl et al. (1997), the understanding of a concrete concept is the identity of the concept, just as an object or conceptual thought can be identified and categorized. Differences in concepts from one another are important in learning because different types of concepts will affect the learning process. Meanwhile, Syahputra and Mahdiana (2019) state that "...the category of understanding includes seven cognitive processes, including: interpreting, providing examples of classifying, summarizing, drawing inferences or concluding, comparing, and explaining". (1) Interpreting is changing from one form of information to another, for example from words to graphics or pictures, or vice versa, from words to numbers, or vice versa, or from words to words, for example summarizing or paraphrasing. (2) Providing means giving an example of a concept or principle of a general nature. Providing examples require the ability to identify the characteristics of a concept and then use those traits to create examples. (3) Classifying means recognizing that something falls into a certain category. (4) Summarizing means making a statement that represents all informations or makes an abstract from an article. (5) Drawing inference means finding a pattern from a series of examples or facts. (6) Comparing means detecting similarities and differences between two objects, ideas or situations. (7) Explaining means constructing and using a causal model in a system.

Understanding the concept of translation is the ability to give the name of a symbol, including determining the name of an image or series of images, the ability to give examples of a symbol or determine examples of images and determine non-examples of images, the ability to define names, examples, attribute and define image objects to be a description. According to Haryanto (1999), translation is the ability to understand not just translation but an abstract connection into one model, namely a symbolic model to make it easier for people to learn or transfer of concepts formulated with words into images, in translating graphics, and applicable understanding. Interpretation, according to Bloom et al. (1971), is the ability to translate. The understanding of image symbols here is that educators can explain by watching television about animals or other images every day, so students will be carried away with the atmosphere in themselves thinking and understanding the concepts that develop following the flow of information they get.

Understanding the concept of interpretation is the ability of students to name the main idea of a communication to determine the name of communication and determine the name between communications, the ability to attribute the main idea of communication, namely mentioning the identity of the object of communication and distinguishing conjunctive, disjunctive and relational concepts. Defining the concept of the main idea of communication is making a concept definition of the object of communication. Communication in this case is in the form of a narrative or description. Students can give names, examples, and attributes to define something. Interpretation, according to Haryanto (1999), is to know and understand the main idea of communication. For example, given diagrams, tables, graphs, pictures in science or physics and interpreted. For example, students can interpret the main idea of a narrative or description. Sudjarwo (1984) states that interpretation is the cognitive aspect of activities carried out to achieve aspects of deep understanding and interpreting learning objects, for example mentioning general categories of communication studied so that students fully understand an object of communication.

The third concept is extrapolation. In this level of understanding, students can name or determine the name of the effect of an object and determine the name of the effect of the association of several objects, give examples or determine examples of the effect of an object and provide non examples of the effect of the association of several objects, give attributes of intrapoxy, namely, mentioning the identity of the object of the incident and distinguish conjugative, disjunctive and correlational concepts from the occurrence of an object, and create concept definitions or define the effects of events. The effect of an object, in this case, is that students are invited to understand a description of the science concept events contained in 
science grade $\mathrm{V}$ subject matter, and they can mention the consequences of these events. The three categories of the conceptual understanding will appear in student in every activity. Because all of his attitudes and behaviors will be seen in his mindset and understanding of the concepts that he has. Extrapolation, according to Bloom et al. (1971), is predicting or summarizing something or an object. Predicting means estimating the effect of an event. According to Sudjarwo (1984), extrapolation contains objectives related to proficiency in applying knowledge and understanding which includes some of what is to be achieved in an exercise. Extrapolation is that students are actively able to decide on an action or determine the consequences of what has been done. In this case, there are four terms of ability including; (1) name the effect of an event, (2) give an example of an event, (3) distinguish whether it is an example or not (3) give an event attribute or general and special classification.

Students' learning achievement is the result of notes made by the teacher about the students' abilities during learning process. The result of those notes are symbol of students' abilities during science learning. If it is related to learning achievement in the field of science, it will be known that the actual scientific achievements of students. Although, many indicators affect the achievement of learning science. However, this study only measures the ability to understand the science concepts and learning achievement in science subjects. The variables discussed in this study are the ability to understand science concepts and achievements in the field of science studies. Learning achievement, according to Winkel (1991), is evidence of success of a business, where the effort carried out requires methods, techniques, and attitudes that must be planned according to the results to be achieved. Meanwhile, Buchori (1982) argues that learning achievement is the result of the achievement of student learning efforts in each period so that each student or is measured in learning achievement in a certain period such as a semester. Meanwhile, Yusuf and Sunarti (1980) state that the factors influencing learning achievement are raw input, or students themselves have different conditions, both physically and psychologically. The next factor is environmental inputs, including environmental, social, and natural factors. The next one is instrumental input or program and learning materials, facilities, teachers, and teaching staff. Purwanto (1997) believes that the factors that influence learning are internal factors in the form of maturity, intelligence, training, and selfmotivation. Meanwhile, external factors are teachers, teaching tools, and other supporting facilities. According to Arifin (1990), learning achievement functions as an indicator of the quality of knowledge, a symbol of curiosity, an indicator of productivity level, an indicator of absorption in learning process.

Science subject is the study of the universe, living things, and objects throughout the universe. Carin and Bass (2001) state that science is a system to know nature or a collection of knowledge that serves to explain what is obtained or a collection of resulting knowledge about the universe and its creatures from time to time using the scientific method. Thus, the next generation can innovate previous works. According to Muakhirin (2014), natural science or science is literally referred to as the science of nature, the science that studies events that occur in nature. Darmojo and Kaligis (1992) explain that science means true knowledge, which means knowledge that is justified according to the benchmarks of the truth of science, namely rational and objective. Besides, knowledge itself is knowledge about the universe and everything in it. Thus, short science is rational and objective knowledge about the universe with all its contents. Darmojo and Kaligis (1992) state that science is a way of looking at the world, that science is a way or method of observing nature, thus, the way science observes this world is analytical, complete, accurate, and connects one phenomenon to other phenomena so that the whole forms a new perspective about the object being observed. Thus, literally, science can also be called as the science of nature or which studies the events that occur in nature.

Susilo (2015) explains that understanding the concept of science has a great contribution to learning outcomes in science subjects. According to Suryani et al. (2016), with a bet-ter understanding of the concept of science, elementary students have achieved learning com- 
pleteness classically very well at 90\%. Meanwhile, Laksana (2016) states that in the last cycle, his research stated that a high understanding of the concept of learning would increase good learning outcomes. The results of this study state that students with a high understanding of the science concepts will improve learning outcomes and satisfying learning completeness.

This research is limited to the problem of understanding the concept of translation or the ability to understand image objects and not just memorizing them, but how to be able to determine names, examples, give attributes and define image objects into descriptions. The concept of interpretation is that students can give examples, attributes, and define the main ideas of communication in the form of narratives and descriptions. Extrapolation is giving names, examples, attributes, and concept definitions of a description of events and mentioning the consequences of these events. The problems that arise in this study can be described as follows: (1) The purpose of activities in elementary school is aimed at improving students' conceptual understanding and they will understand its relationship with daily life, but the fact is many schools use teaching and learning activities with the ultimate goal of only memorizing subject matter, (2) elementary school students in grade $\mathrm{V}$, according to their age in translation ability, should be able to understand in seeing image objects. Therefore, their supporting factors should still be reproduced in the learning process using image media and real examples, (3) understanding the concept includes the ability to understand a communication idea, namely the ability to interpret, if there is a failure in understanding the idea of communication it will cause students cannot develop further abilities because the basic idea cannot be mastered, (4) meanwhile, understanding the concept of interpretation is the ability to make estimate to predict an outcome that will arise. This will allow the students to determine their attitude in acting. Overall, it can be predicted that if students have a high understanding of concepts in the field of science, it will also increase high learning achievement, both in science subjects in particular and in general for other subjects.

Thus, the problem is formulated as follows: (1) there is a correlation between translation abilities on student achievement in science subjects, (2) there is a correlation between interpretation ability on student achievement in science subjects, (3) there is a correlation between interpretation ability of students on student achievement in science subjects, and (4) there is a correlation between the ability of translation, interpretation, and extrapolation on student achievement in science subjects. The relationship between translation, interpretation, extrapolation of science concepts with science learning achievement is the ability to determine names, examples, and attribute and define images, main ideas of communication and determine the consequences of an event, this is a form of understanding the concept which is one of the factors support in the level of students' learning achievement, especially in the mindset and attitude of students.

\section{RESEARCH METHOD}

To facilitate the authors to carry out the research, the research scheme was elaborated as follows. (1) There was a correlation in students between the translation ability and learning achievement. (2) There was a correlation between interpretation ability and learning achievement. (3) There was a correlation between extrapolation ability and learning achievement. Lastly, there was a correlation between translation, interpretation, extrapolation ability on the achievement of science subjects. More details can be seen in the scheme in Figure 1.

This study is a descriptive quantitative research that collected as much data as possible about the supporting factors to the ability of translation, interpretation, and extrapolation and then analyzed the factors sought its role to the achievement of science. The population was the entire subject of the study according to Arikunto (2001). Meanwhile, in this study, all elementary school students in grade V at SDN Banyak Prodo I in Tirtomoyo Subdistrict, Wonogiri, Central Java. This study used a total sampling of 48 students. 
202 - Sri Wuryanti, Deni Hadiana, \& Rumondang Purwati

doi doi:https://doi.org/10.21831/pep.v24i2.35730

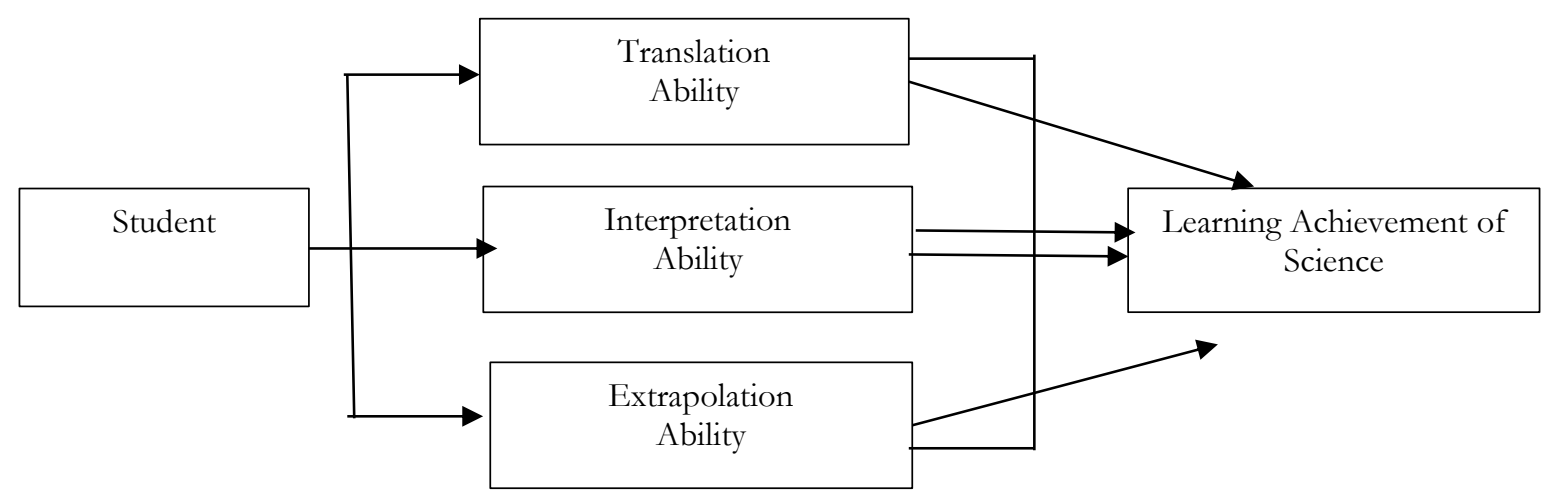

Figure 1. The Scheme of Research Framework

Meanwhile, this research technique used concept understanding test with variables used for the test. The statements submitted about the understanding the concept of science were as follows: (1) The ability of science concept translation, including (a) giving the symbol name, (b) giving examples of symbol, (c) giving symbol attributes, and (d) defining the symbol. (2) The ability of science interpretation, including (a) giving the main idea of communication, (b) giving examples of main idea of communication, (c) giving the main attribute of communication, and (d) providing definitions of the main concept of communication. (3) The ability of science interpretation includes (a) giving the name of intrapoxy, (b) giving an example of intrapoxy, (c) giving the attribute of intrapoxy, and (d) giving the definition of intrapoxy concept.

The validity of the data used the judgment of material science experts then held a tryout to the students and held the construct validity by using the product-moment formula statistical method. The results of the analysis could be described as follows, the average level of difficulty of the entire tests: 0.490 biserially, this test had a moderate level of difficulty. For the average coefficient of all biserial point orations of the entire these tests, the total item was 0.583 , and the biserial average: 0.777 . The differentiating power was very satisfying so that the instrument was worth using. For the total 30 questions made, 21 items were missing, while nine items were revised. For the overall reliability test with ITEMAN, the result is as follows: 0.930 and according to SPS with Alpha $r_{t t}=0.962$. It means that the question had a very reliable level. The documentation technique in this research was conducted by collecting students' science learning achievement scores from grade III to $\mathrm{V}$ in the first semester.

\section{FINDINGS AND DISCUSSION}

\section{Findings}

\section{Translation Ability}

In term of the translation ability from the data collection, the highest score is 30 and the lowest score is 14 . The standard deviation is 3.93 with a mean of 23.71 . The complete data can be seen in Table 1, which can also be presented into a graph of translation ability concept, as shown in Figure 2.

Table 1. Frequency Distribution of Science Concept Translations

\begin{tabular}{ccc}
\hline Interval & Frequency & Percentage (\%) \\
\hline $26-30$ & 7 & 14.58 \\
$22-26$ & 25 & 52.08 \\
$18-22$ & 11 & 22.92 \\
$14-18$ & 15 & 10.49 \\
Total & $\mathbf{4 8}$ & $\mathbf{1 0 0 . 0 0}$ \\
\hline
\end{tabular}


203 - Sri Wuryanti, Deni Hadiana, \& Rumondang Purwati

doiddoi:https://doi.org/10.21831/pep.v24i2.35730

TRANSLATION ABILITY CONCEPT

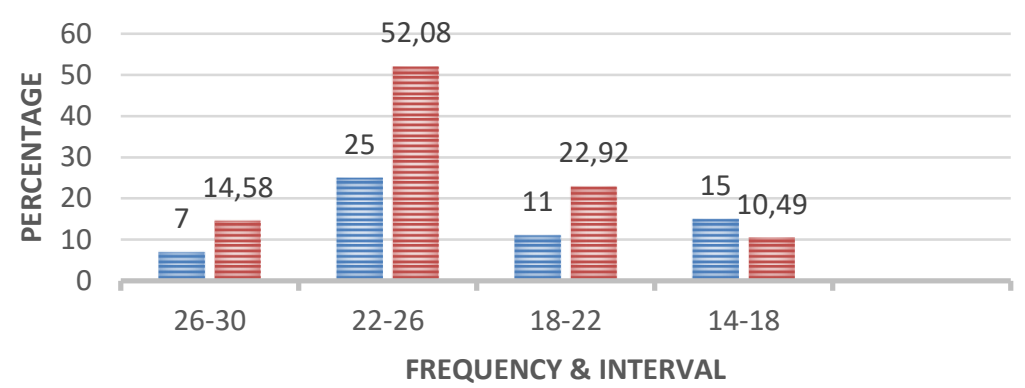

Figure 2. Graph of Translation Ability

\section{Interpretation Ability}

The result of data collection on the highest score of interpretation ability is 30 and the lowest score is 10 . The standard deviation is 4.88 with a mean of 22.10 . The complete data can be seen in Table 2 and Figure 3.

Table 2. Frequency Distribution of the Interpretation of Science Concepts

\begin{tabular}{ccc}
\hline Interval & Frequency & Percentage (\%) \\
\hline $26-30$ & 16 & 33.33 \\
$22-26$ & 15 & 31.25 \\
$18-22$ & 14 & 29.17 \\
$14-18$ & 3 & 6.25 \\
Total & $\mathbf{4 8}$ & $\mathbf{1 0 0}$ \\
\hline
\end{tabular}

\section{INTERPRETATION ABILITY CONCEPT}

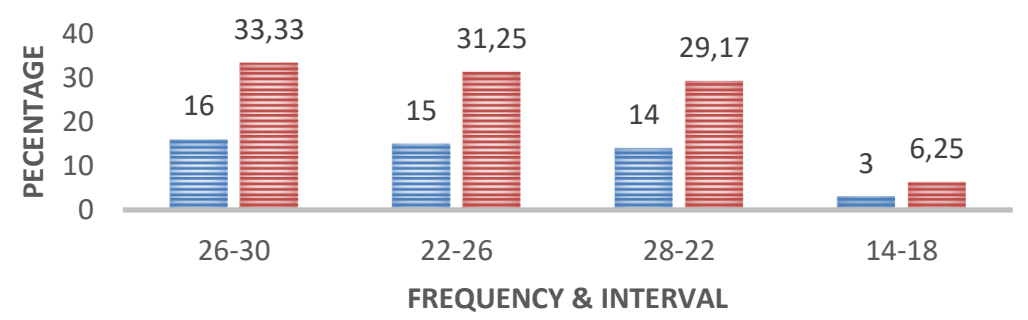

Figure 3. Graph of the Ability to Interpret the Concept of Science

\section{Extrapolation Ability}

The results of the data collection on the extrapolation ability of the science concept obtain a deviation of 5.50 with a mean of 20.13 . The complete data can be seen in Table 3 , which can also be graphed in the picture of the four extrapolation ability as presented in Figure 4.

Table 3. Extrapolation Frequency Distribution of Science Concepts

\begin{tabular}{ccc}
\hline Interval & Frequency & Percentage (\%) \\
\hline $26-30$ & 20 & 41.67 \\
$22-26$ & 13 & 27.08 \\
$18-22$ & 17 & 35.42 \\
$14-18$ & 8 & 16.67 \\
Total & $\mathbf{4 8}$ & $\mathbf{1 0 0 . 0 0}$ \\
\hline
\end{tabular}




\section{EXTRAPOLATION ABILITY CONCEPT}

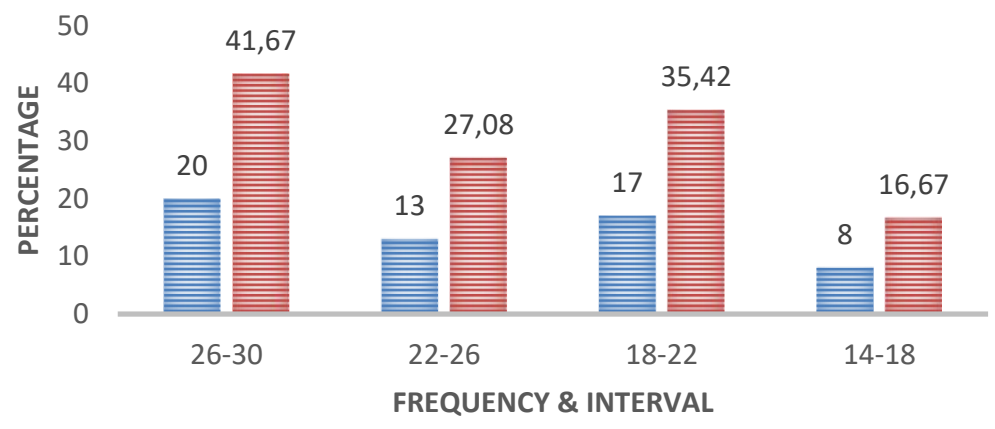

Figure 4. Graph of the Extrapolation Ability of the Science Concept

\section{Learning Achievement of Four Science Subjects}

The results of data collection regarding learning achievement in the science subjects obtain the highest score of 8.43 and the lowest score of 5.29. The standard deviation is 66.97 with a mean of 64.058. The complete data can be seen in Table 4 and Figure 5.

Table 4. Frequency Distribution of Science Learning Achievement

\begin{tabular}{ccc}
\hline Interval & Frequency & Percentage (\%) \\
\hline $26-30$ & 16 & 33.33 \\
$22-26$ & 21 & 43.75 \\
$18-22$ & 10 & 20.83 \\
$14-18$ & 1 & 2.08 \\
Total & $\mathbf{4 8}$ & $\mathbf{1 0 0 . 0 0}$ \\
\hline
\end{tabular}

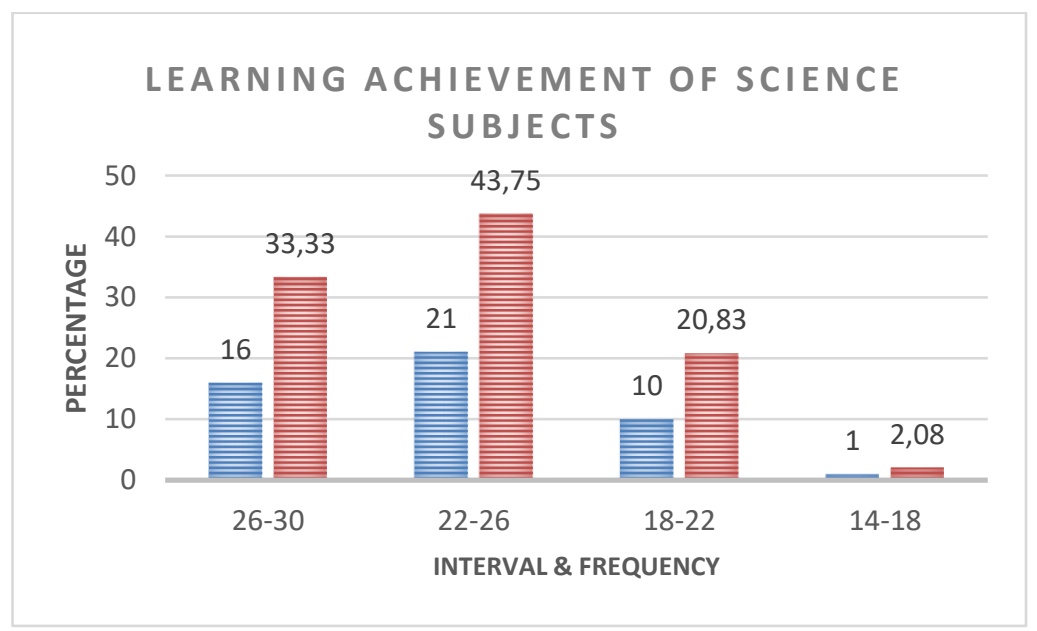

Figure 5. Graph of Learning Achievement in the Field of Science Subjects

\section{Hypothesis Testing}

The results of the multiple regression analysis of this study are presented in Table 5 . It can be found that the correlation between translation ability and the level of achievement in learning science is 0.231 with $\mathrm{N}$ : 48 and a significance level of $1 \%$ is obtained $\mathrm{r}$ table 0.057 . After being consulted with $\mathrm{r}$ table, it turns out that ro $>\mathrm{rt}$, then it is known that the translation ability with the level of students learning achievement in science subjects is significant. 
205 - Sri Wuryanti, Deni Hadiana, \& Rumondang Purwati

doiddoi:https://doi.org/10.21831/pep.v24i2.35730

Table 5. Summary of Product Moment Analysis Results

\begin{tabular}{|c|c|c|c|c|}
\hline & Mean Score & $\begin{array}{c}\text { Translation } \\
\text { Ability }\end{array}$ & $\begin{array}{c}\text { Interpretation } \\
\text { Ability }\end{array}$ & $\begin{array}{c}\text { Extrapolation } \\
\text { Ability }\end{array}$ \\
\hline \multicolumn{5}{|l|}{ Pearson Corr } \\
\hline Mean Score of Science & 1.000 & .231 & .401 & .420 \\
\hline Translation Ability & .231 & 1.000 & .745 & .648 \\
\hline Interpretation Ability & .401 & .745 & 1.000 & .714 \\
\hline Extrapolation Ability & .420 & .648 & .714 & 1.000 \\
\hline \multicolumn{5}{|l|}{ Sig(1-tailed) } \\
\hline Mean Score of Science & . & 0.57 & 002 & .001 \\
\hline Translation Ability & .057 & . & 000 & .000 \\
\hline Interpretation Ability & .002 & .000 & . & .000 \\
\hline Extrapolation Ability & .001 & .000 & .000 & \\
\hline \multicolumn{5}{|l|}{$\underline{\mathrm{N}}$} \\
\hline Mean Score of Science & 48 & 48 & 48 & 48 \\
\hline Translation Ability & 48 & 48 & 48 & 48 \\
\hline Interpretation Ability & 48 & 48 & 48 & 48 \\
\hline Extrapolation Ability & 48 & 48 & 48 & 48 \\
\hline
\end{tabular}

Meanwhile, the correlation between interpretation ability and the level of scientific learning achievement was 0.401 with $\mathrm{N}$ : 48 and a significance level of $1 \%$, the $\mathrm{r}$ table was 0.002. After being consulted with the $\mathrm{r}$ table, it turns out that ro $>\mathrm{rt}$ from the level of significance of $1 \%$, then it is known that the correlation between translation ability and the level of achievement of science subjects is very significant.

The correlation between extrapolation ability and student achievement level in science learning achievement is 0.420 with $\mathrm{N}$ : 40 and a significance level of $1 \%$ is obtained $\mathrm{r}$ table 0.0001. After being consulted with the $\mathrm{r}$ table, it turns out that ro $>\mathrm{rt}$ from the $1 \%$ significance level, it is known that the correlation between extrapolation ability and achievement level of science subjects is very significant. The results of the multiple regression test on the correlation coefficient are presented in Table 6 .

Table 6. Summary of Multiple Regression Analysis

\begin{tabular}{cccccc}
\hline Model & Sum of Squares & Df & Mean Square & F & Sig. \\
\hline Regression & 4.653 & 3 & 1.551 & $011^{2}$ \\
Residual & 16.429 & 44 & 0.373 & & \\
Total & $\mathbf{2 1 . 0 8 2}$ & $\mathbf{4 7}$ & & & \\
\hline
\end{tabular}

From the results of the multiple regression analysis, $\mathrm{Fo}_{\mathrm{O}}=4.154$ with $\mathrm{df}=3: 44$ and a significance level of $1 \%$ obtained $r$ table 0.221 . After being consulted with the $r$ table, it turns out that $\mathrm{Fo}>\mathrm{rt}$ is from the $1 \%$ significance level, it is known that the correla-tion between extrapolation ability and the level of achievement in science subjects is very sig-nificant.

\section{Discussion}

In this study, it is known that there is an effect of translation ability on learning achievement in science subjects with an effective contribution of $23.71 \%$. Thus, the changes in the variance of the translation ability scores on learning achievement science subjects of 0.231 . it means that the increase in the score of translation ability is followed by an increase in the score of learning achievement in science subjects. According to Bloom et al. (1971), there is a positive influence on the translation ability of science learning achievement. From the analysis, it is known that the effective contribution of translation ability to change in learning achievement is $23.71 \%$. This influence is seen to be the highest compared to the ability of the two understandings. 
In addition, it was also proven that there was an effect of interpretation ability on the learning achievement of midwives in science studies with an effective contribution of $22.10 \%$. Therefore, changes in the variance of interpretation ability scores can explain changes in the variance of learning achievement scores in the field of science subjects by $22.10 \%$. The correlation between interpretation ability on learning achievement in the field of science subjects is 0.401 . Therefore, it means that an increase in the score of interpretation ability is followed by an increase in the score of learning achievement in science, and vice versa, a decrease in interpretation ability is followed by a decrease in the score of achievement in the field of science subjects.

Furthermore, it was proven that there was an effect of extrapolation ability on learning achievement in the field of science with an effective contribution of $20.13 \%$. Therefore, the changes in the variance of the extrapolation ability score can explain the changes in the variance of the learning achievement score in the field of science subjects by $20.13 \%$. The correlation between extrapolation ability on science learning achievement is 0.420 . It means that the increase in the extrapolation ability score is followed by an increase in the science learning achievement score and conversely the decrease in the extrapolation ability score is followed by a decrease in the achievement score in the field of science subjects.

In this study, it was proven that there was an effect of the three abilities of the concepts of translation, interpretation and extrapolation on learning achievement in the field of science subjects with an effective contribution of $65.94 \%$. Therefore, changes in the variance of scores for the ability of translation, interpretation, and extrapolation can explain changes in the variance of achievement scores in science subjects by 0.420 . It means that an increase in the score for the ability of translation, interpretation, and extrapolation is followed by an increase in the score of learning achievement in science subjects and vice versa a decrease in the ability of translation, interpretation, and extrapolation is followed by a decrease in the score of achievement in science subjects.

\section{CONCLUSION}

Based on the research results, it can be seen that (1) there is a correlation between translation ability and the level of science learning achievement of grade $\mathrm{V}$ students, the significance level is satisfactory. This means that an increase in the score of interpretation ability is followed by an increase in the score of learning achievement in science and conversely a decrease in the ability in interpretation is followed by a decrease in the score of achievement in science subjects. Besides, (2) there is a correlation between the interpretation ability and the level of science learning achievement of grade $\mathrm{V}$ students, the significance level is satisfactory. This means that an increase in the score of interpretation ability is followed by an increase in the score of learning achievement in science and conversely a decrease in the ability in interpretation is followed by a decrease in the score of achievement in science subjects. In addition, (3) there is a correlation between extrapolation abilities and the level of science learning achievement of class $V$ students, the significance level is very satisfactory. This means that an increase in the extrapolation ability score followed by an increase in the science learning achievement score and conversely a decrease in the extrapolation ability score is followed by a decrease in the achievement score of science subjects. Finally, (4) there is a correlation between the ability of translation, interpretation, and extrapolation and the science learning achievement of grade $\mathrm{V}$ students, the level of significance is very satisfactory. This means that an increase in the score for the ability of translation, interpretation, and extrapolation is followed by an increase in the score of learning achievement in science, and conversely, a decrease in the ability of translation, interpretation, and extrapolation is followed by a decrease in the score of achievement in science subjects. 


\section{REFERENCES}

Arifin, Z. (1990). Evaluasi instruksional prinsip-praktek-prosedur. Remaja Rosdakarya.

Arends, R. I. (2001). Learning to teach (5th ed.). McGraw Hill.

Bloom, B. S., Hastings, J. T., \& Madaus, G. F. (1971). Handbook on formative and summative evaluation of student learning. McGraw Hill.

Seymour, B. J. (1966). Study psicology cognitif. Harvard University.

Buchori, M. (1982). Evaluasi dalam pendidikan. Rineka Cipta.

Crowl, T. K., Kaminsky, S., \& Podell, D. M. (1997). Educational psychology: Windows on teaching. McGraw Hill.

Darmojo, H., \& Kaligis, J. R. F. (1992). Pendidikan IPA II. Departemen Pendidikan dan Kebudayaan, Direktorat Jenderal Penddiikan Tinggi Proyek Pembinaan Tenaga Kependidikan.

Haryanto, H. (1999). Ilmu pengetahuan alam: Jilid 3. Erlangga.

Hurlock, E. B. (1990). Psikologi perkembangan. Erlangga.

Laksana, D. N. L. (2016). Miskonsepsi dalam materi IPA sekolah dasar. Jurnal Pendidikan Indonesia, 5(2), 166-175. https://doi.org/10.23887/jpi-undiksha.v5i2.8588

Muakhirin, B. (2014). Peningkatan hasil belajar IPA melalui pendekatan pembelajaran inkuiri pada siswa SD. Jurnal Ilmiah Guru Caraka Olab Pikir Edukatif, O(1), 51-57.

Purwanto, N. (1997). Psikologi perkembangan. Remaja Rosdakarya.

Sudjarwo, S. (1984). Teknologi pendidikan. Gelora Aksara Pratama.

Arikunto, S. (2001). Prosedur penelitian pendekatan praktek. Rineka Cipta.

Carin, A. A., \& Bass, J. E. (2001). Teaching science as inquiry. Prentice Hall.

Suryani, E., Rusilowati, A., \& Wardono, W. (2016). Analisis pemahaman konsep IPA siswa SD menggunakan two-tier test melalui pembelajaran konflik kognitif. Journal of Primary Education, 5(1), 56-65. https://doi.org/10.15294/jpe.v5i1.12893

Susilo, L. (2015). Peningkatan hasil belajar pendidikan kewarganegaraan dengan menggunakan metode bermain peran di sekolah dasar kabupaten tanah tidung. Jurnal Pendidikan Dasar, 6(1), 24-35. https://doi.org/10.21009/JPD.061.03

Syahputra, M. A. D., \& Mahdiana, N. (2019). Analysis of history textbooks based on benedict anderson's approach. Historika, 22(2), 21-36. https://doi.org/10.20961/historika.v22i2. 37962

Winkel, W. S. (1991). Psikologi belajar. Rajawali.

Yusuf, M., \& Sunarti, B. (1980). Panduan komunikasi informasi dan edukasi. Lab. PLB FKIP UNS. 